\title{
Habitat destruction in wetland affects Ostracoda (Crustacea) species occurrence patterns amid different aquatic habitats
}

\author{
Okan Külköylüoğlu ( $•$ Beyza Çelikbaş • Alper Ataman
}

Received: 1 October 2021 / Accepted: 10 December 2021 / Published online: 6 January 2022

(C) The Author(s), under exclusive licence to Springer Nature B.V. 2022

\begin{abstract}
To outline influence of anthropogenic activities on natural aquatic habitats such as wetlands, we sampled ostracods along with measuring several different aquatic variables at four different aquatic bodies between 2019 and 2020 in the Hidirşeyhler Village (Bolu, Turkey). We found 15 living and 10 subfossil ostracods. Species with high tolerances (Eucypris virens) and/or with swimming abilities (Cypria ophtalmica) were reported from the canal and wetland. Non-swimmer ostracods (e.g., Prionocypris zenkeri) were only found from the creek. Ostracod Watch Model illustrated some species with stenochronal and eurychronal (e.g., Heterocypris incongruens) occurrences per site. CCA results displayed that water temperature and electrical conductivity were the most important explanatory variables on species. Unbiased diversity indices revealed the highest diversity in the canal followed by the creek, wetland, and trough. Wetland diversity exhibited positive and negative correlations with the canal and the creek, respectively. Tukey's pairwise test supported the significant comparisons between the trough, canal, and wetland $(p<0.01)$. The ratio of tolerant species per station was slightly higher in the canal than
\end{abstract}

Handling Editor: S.S.S. Sarma.

O. Külköylüoğlu $(\bowtie) \cdot$ B. Çelikbaş · A. Ataman Department of Biology, Faculty of Arts and Science, Bolu Abant İzzet Baysal University, Bolu, Turkey

e-mail: kulkoyluoglu_o@ibu.edu.tr the wetland, trough, and creek. This suggests the fact that species encountered from the creek seem to be habitat specific and may be considered more vulnerable to changes in aquatic conditions. Frequency of species encountered in three habitats (wetland, canal, and trough) was significantly changed after the construction (digging and converting the wetland) activities began in August 2019. This activity was a negative impact on species diversity and richness in the wetland area where the diversity sharply dropped down and did not recover during the study. In contrast, this was probably advantage for some cosmoecious species.

Keywords Ostracod watch model $\cdot$ Habitat destruction $\cdot$ Species diversity $\cdot$ Ecological tolerance . Habitat preferences $\cdot$ Cosmoecious species

\section{Introduction}

Aquatic habitats are one of the most sensitive and critical habitats affected more by human activities than natural causes. They are considered as important water bodies due to their limnoecological, biological, social, and economic role in ecosystem function and sustainability (Herath 2004; Mitsch and Gosselink 2015; Zhang et al. 2011). Although contributions of the wetlands to improve health and structure of the 
ecosystem cannot be scientifically ignored worldwide, they are under the threats of human activities in Turkey (Uçak et al. 2014). Indeed, most recently, Ataol and Onmuş (2021) estimated that about 21.2\% of the wetlands (ca. 291,339 ha) were lost within the last hundred years in Turkey. This corresponds to reduction in the numbers of original wetlands from 1299 to 900 by the year 2014. As the authors pointed out, wetland drainage was one of the most and main critical factors on this loss of habitat.

Ostracods are known as one of the most diverse aquatic microscopic crustaceans and have two valves (called carapace) which are mostly made of $\mathrm{CaCO}_{3}$. The carapace covering the soft body parts is mainly moved by central muscles and hinge structures. More than 65,000 fossil and living species are known (Kempf 1980, 1997; Meisch 2000b; Karanovic 2012) from a variety of marine, brackish, and freshwater habitats. Most currently about 2340 of them are known from nonmarine aquatic habitats (Meisch et al. 2019; Külköylüoğlu et al. 2020a, 2021). Ostracods can be found as fossils from different levels of substrates and/ or geological formations. Hence, studies (Delorme 1991; Williams et al. 2008; Ozawa 2013) reported that origins of ostracods can be dated back to the Cambrian age (ca. 500 mya). This gives possibilities of comparing the past and present changes in habitat conditions and species assemblages since each species has its own individual habitat and ecological preferences. Ecological characteristics of species can be related to the habitats inhabited by the animals (Külköylüoğlu 2000). Accordingly, the present knowledge about ostracod occurrences along with their ecology and habitat preferences aids to interpret past historical conditions of the habitats. Ostracods reveal different ecological tolerance and optimum levels to different environmental variables (Wise 1961; Delorme 1991; Meisch 2000b; Yavuzatmaca 2019; Gürer and Külköylüoğlu 2019). Ostracods can have wide geographical ranges since they have desiccation resistant eggs (Horne 1993) which can be dispersed by means of passive (e.g., birds, fish, wind, water flow) (Proctor 1964; Vinyard 1979; Scharf et al. 2016) or active (i.e., swimming) methods. Despite the fact that ostracods can be useful proxies from different perspectives of biological, ecological, taxonomic, and evolutionary reasons, their monthly and/or seasonal occurrences are not well known in wetlands and related habitats nearby. This is especially true when such habitats are under the threats of human activities. However, comparing to short term and/or one time sampling efforts, it appears that the monthly or seasonal samplings in a particular area(s) can provide broader ecological and biological information about not only species occurrence strategies but also their habitat preferences (Külköylüoğlu 1998; Külköylüoğlu et al. 2012) and true species diversity.

Many nonmarine ostracods are known to have variations in their seasonal occurrences (Hoff 1943; Külköylüoğlu 1998, 1999; Rossetti et al. 2004). If trends of species occurrences within a certain period(s) of seasons or months are known, this information can be crucially helpful for interpreting ecological characteristics of that area(s). This includes obtaining alpha and gamma species diversity measures of the habitats. Gürer and Külköylüoğlu (2019) argued that ostracod diversity can thus be related to habitat types and may show differences between artificial (e.g., troughs, canal) and natural habitats (e.g., creeks, wetlands). Although these authors stated that seasonality and diversity can have different levels of influences on habitat types, there are some opposite results (e.g., see Külköylüoğlu 2009; Külköylüoğlu et al. 2017a,b) which indicate that variety of biotic and/or abiotic factors can be effective on species occurrences. During the present study, we were not able to include biotic factors on our analyses, but several abiotic factors were measured in situ.

Generally, in ostracod studies, one of the aims is to disentangle variations in species seasonal and/or monthly occurrence patterns amid different aquatic habitats. This is also essential to understand correlational patterns of species ecological requirements and their influence on local (or regional) biodiversity values (Gürer and Külköylüoğlu 2019). Up to now, as far as we know, there are no long-term (i.e., monthly samplings more than a year) studies on nonmarine ostracods in four different habitats located in the same region covering about $900 \mathrm{~m}^{2}$. Thereby, we hypothesize that species with broad ecological tolerances can be expected to have longer and continuous occurrences in more different habitats than species with narrow tolerance ranges. Expected rationality of this hypothesis is that if supported, we can estimate that species with narrow tolerances would be limited in distribution and occurrences in certain kinds of habitats and/or conditions and can be affected by environmental fluctuations more than those of tolerant 
species. Accordingly, the present study aims to (1) complete first long term samplings in four different habitat types within about $900 \mathrm{~m}^{2}$ of area around Hıdırşeyhler wetland (Bolu, Turkey), (2) test the hypothesis "No difference in the mean of occurrences between the species with broad and narrow ecological tolerances to different environmental variables," (3) compare species (i.e., tolerant, non-tolerant, swimmer, non-swimmer) ecological preferences among the habitats, and (4) show how anthropogenic activities affect the species composition and all diversity.

\section{Materials and methods}

Samples (4040“804’N; 31 35”768'E) were collected monthly from four different habitats (a trough (Unutma Beni Çeşmesi), a creek (unnamed), a wetland (aka Hıdırşeyhler wetland), a canal) which were visited from 15 May 2019 to 26 June 2020. We did not collect samples in April 2020 due to restriction of pandemic rules by the government. All the sites (Fig. 1) are located at ca. $745 \mathrm{~m}$ asl within the border of Hıdırşeyhler Village (Bolu, Turkey) and located within ca. $900 \mathrm{~m}^{2}$ area. The natural wetland is semicircular in shape with a maximum depth of about $3 \mathrm{~m}$ at the center. The concrete trough is about $430 \mathrm{~cm}$ long, $50 \mathrm{~cm}$ deep, and $40 \mathrm{~cm}$ wide. It is used to provide water for cattle. Including the flooding zone, the wetland covers a ca. $462 \mathrm{~m}^{2}$ area. The natural creek site (aka Hıdırşeyhler Deresi) is ca. $2 \mathrm{~m}$ wide and $30 \mathrm{~cm}$ deep where the samples were taken. Hıdırşeyhler wetland (aka Hıdırşeyhler sazlığ maintained by a canal flowing from surrounding agricultural fields. In other words, the wetland and the canal were intact at the beginning of our study. These two sites (canal and wetland) were sampled around the wetland for the first three months of the sampling period. However, in August 2019, recreation activities to improve local touristic visits to the area began. For this purpose, excavation with bulldozers and removal of reed bed (Phragmites sp.)

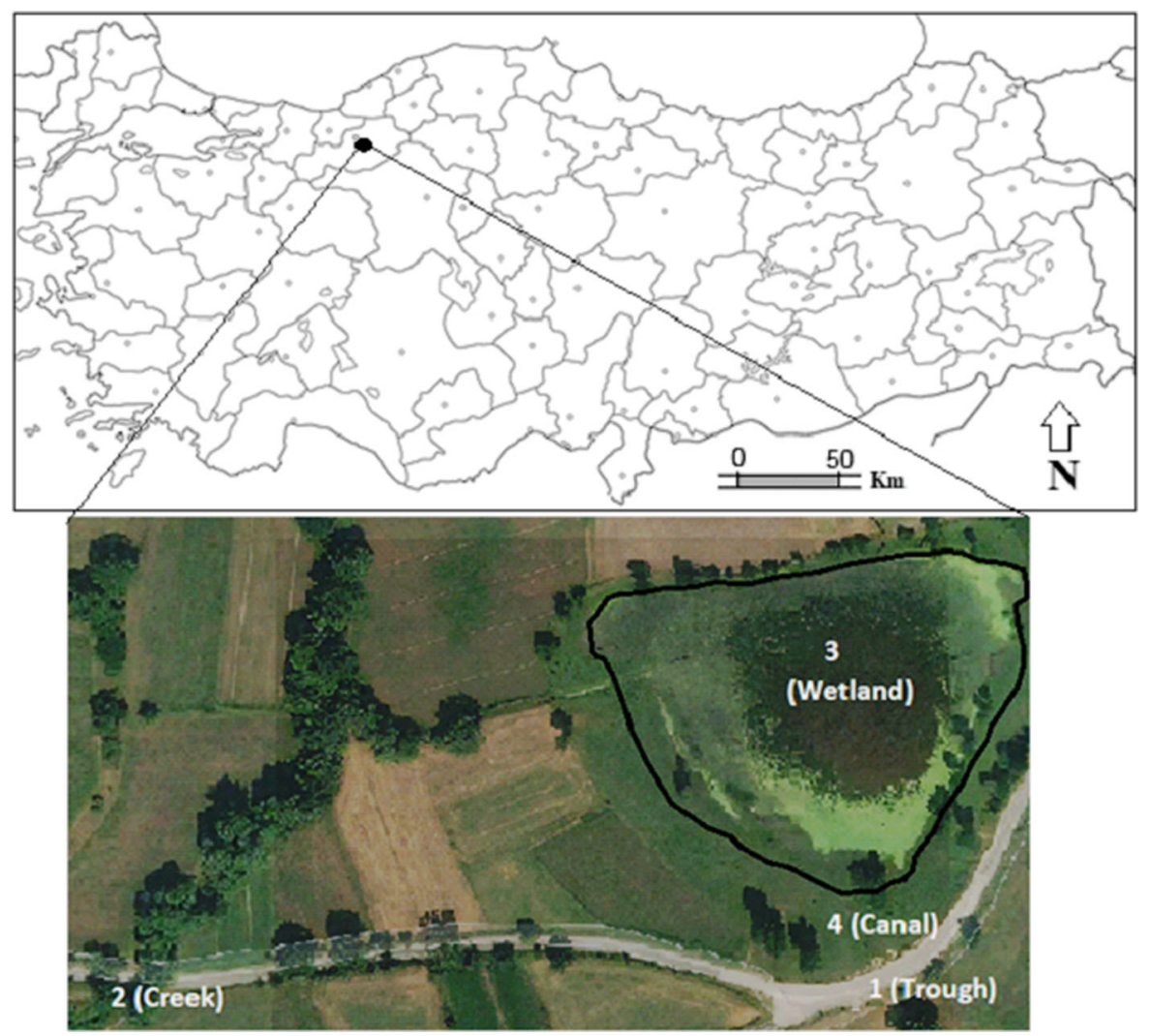

Fig. 1 Map of sampling sites in Bolu, Turkey. The wetland is of ca. $462 \mathrm{~m}^{2}$ area 
communities begun in the area. Moreover, this caused separation of the canal from the main part of the wetland. We continued to sample the sites until the end of the study. This allowed us to make comparisons before and after the impact of the separation.

We used a phytoplankton hand net $(125 \mathrm{~mm}$ mesh size) for sampling the shallow waters (maximum depth $30 \mathrm{~cm}$ ). YSI-Multiprobe Professional plus was used to measure water temperature $\left({ }^{\circ} \mathrm{C}\right), \mathrm{pH}$, dissolved oxygen $(\mathrm{mg} / \mathrm{L})$, oxygen saturation $(\% \mathrm{DO})$, electrical conductivity $(\mu \mathrm{S} / \mathrm{cm})$, salinity (ppt), total dissolved solids $(\mathrm{mg} / \mathrm{L})$. In order to reduce and/or eliminate possible effects of pseudoreplication (Hurlbert 1984), (1) we visited each site and samples were collected separately and (2) water measurements were done before sediment samples were taken. Air temperature $\left({ }^{\circ} \mathrm{C}\right)$, atmospheric pressure $(\mathrm{mmHg})$, humidity $(\%)$ and wind speed $(\mathrm{m} / \mathrm{s})$ were measured with Etrex Anemometer in situ. Coordinates and elevation were recorded with GPS (eTrex Vista HCX, Garmin) for each of the sites. About $200 \mathrm{ml}$ of sediment and water samples were collected and fixed in $70 \%$ of alcohol in glass bottles. Samples were filtered from three standard sieves $(0.25,0.5$, and $1.0 \mathrm{~mm}$ mesh size $)$ in the laboratory and kept in $70 \%$ alcohol for further analyses. Species separation from the sediment was done with pipets and needles under a stereomicroscope under which dissections of the specimens were also done with fine needles within lactophenol solution. Following dissection, specimens were covered with a cover slip. We mainly followed systematic keys of Meisch (2000) for species identification. Each slide is numbered and deposited at the Limnological Laboratory of the Department of Biology, Bolu Abant Izzet Baysal University. They can be available upon request from the corresponding author.

During the statistical analyses, we used binary (present-absent) data for all taxa including subfossils and recent (live) samples. Canonical correspondence analysis, a multidimensional exploratory statistical method, was used to illustrate possible correlations between species and environmental variables for 44 samplings combined during the study. Accordingly, we use 16 taxa (response variables) and four major explanatory environmental variables (dissolved oxygen, $\mathrm{pH}$, electrical conductivity, and water temperature). Note that Potamocypris sp. included only one live female and one juvenile collected from two different months when Limnocythere sp. had only one live female. However, we know that both might have males. Since we did not have males, we preferred to keep them as "sp." and not included into the analyses as explained in the text and table caption. Before CCA, we run Detrended Correspondence Analyses (DCA) to understand suitability of the data for CCA along with using Monte Carlo test (499 permutations). Random and rare species were automatically downloaded by the program (ter Braak 1986) to protect multicolinearity of the data. Finding the length of DCA (3.9) over 3 or more supported that our data was suitable for the CCA.

Species ecological optimum and tolerance values were calculated with $\mathrm{C} 2$ software program (Juggins 2003), during which the transfer function of weighted averaging regression along with binary data was used for each species encountered live from three or more different times. PAST 4.03 program was used for the normality tests, unbiased diversity analyses with 9999 bootstrap along with providing plots. Microsoft Excel 97-2003 program was run for calculating the descriptive analyses. Ostracod Watch Model (Külköylüoğlu 1998) was used to show species monthly occurrences.

\section{Results and discussion}

A total of 25 ostracod taxa (15 living and 10 subfossils) were found from all sites combined including 13 taxa from the creek, 2 from the trough, 16 from the canal, and 11 from the wetland (Table 1). The ratio of tolerant species found in each site was higher in canal than other three sites. This suggests that species encountered from the creek seem to be habitat specific and may be considered more vulnerable to changes in aquatic conditions. All species were almost found within their expected ecological ranges (Table 2). Habitat preferences of some species were clearly identified; for instance, Herpetocypris brevicaudata Kaufmann, Psychrodromus olivaceus (Brady and Norman), and Prionocypris zenkeri (Chyzer and Toth) were only found in creek, but a single and most common cosmoecious species (Heterocypris incongruens (Ramdohr)) was collected from the trough. Species (e.g., Eucypris virens (Jurine)) known with high tolerance levels to different environmental variables and/or two swimming species (Cyclocypris laevis (O.F. Müller), Cypria ophtalmica (Jurine)) were only reported from the canal and wetland with 
Table 1 List of taxa and the ratio of tolerant species per site. Presence of species is shown with $\mathrm{P}$ when $\mathrm{T}$ and $\mathrm{J}$ indicate tolerant adult species and juveniles, respectively. Darwinula sp. was only found with one left valve broken and not accounted in calculation. Due to lack of sufficient material, we could not observe both valves of the individual from
Darwinula. However, there is sufficient support that this genus is monospecific. Species of the canal and the wetland were listed before (15.05.2019-18.08.2019) and after construction (24.09.2019-26.06.2020). *No diversion or any other habitat disturbance was recognized during the study. V, valves; C, carapace

\begin{tabular}{|c|c|c|c|c|c|c|}
\hline Taxa & Wetland before & Wetland after & Trough & Creek* & Canal before & Canal after \\
\hline Pseudocandona sp1 & $\mathrm{C}$ & $\mathrm{V}$ & & $\mathrm{P}$ & $\mathrm{J}$ & V \\
\hline Neglecandona neglecta & $\mathrm{CJ}$ & $\mathrm{CJ}$ & & TP & TP & TP \\
\hline Fabaeformiscandona fabaeformis & & & & & $P$ & $\mathrm{C}$ \\
\hline Candona sanociensis & $\mathrm{P}$ & $\mathrm{C}$ & & $\mathrm{P}$ & $\mathrm{P}$ & $\mathrm{P}$ \\
\hline Candona sp1 & & & & $P$ & & $\mathrm{~V}$ \\
\hline Cyclocypris laevis & $\mathrm{P}$ & $\mathrm{C}$ & & & $\mathrm{P}$ & $\mathrm{P}$ \\
\hline Cypria ophtalmica & TP & $\mathrm{TP}$ & & & TP & TP \\
\hline Darwinula sp. & & & & & $\mathrm{V}$ & \\
\hline Herpetocypris brevicaudata & & $\mathrm{C}$ & & $\mathrm{P}$ & & \\
\hline Psychrodromus olivaceus & & & & $\mathrm{TP}$ & & \\
\hline Prionocypris zenkeri & & & & $\mathrm{TP}$ & & \\
\hline Eucypris virens & $\mathrm{TP}$ & & & & TP & TP \\
\hline Eucypris sp. & & & & $\mathrm{P}$ & & \\
\hline Potamocypris $\mathrm{sp} 1$ & & $\mathrm{P}$ & & $\mathrm{P}$ & & \\
\hline Heterocypris $\mathrm{sp} 1$ & & & & $\mathrm{P}$ & & \\
\hline Heterocypris incongruens & & TP & TP & & & TP \\
\hline Heterocypris salina & & & & & & TP \\
\hline Ostracod indent & & & $\mathrm{P}$ & & & \\
\hline Ilyocypris gibba & & & & & & $P$ \\
\hline Ilyocypris bradyi & & & & & & TP \\
\hline Ilyocypris inermis & & $\mathrm{TP}$ & & $\mathrm{TP}$ & & TP \\
\hline Cypris cf. pubera O.F. Müller & & $\mathrm{CJ}$ & & & & $\mathrm{VJ}$ \\
\hline Tonnacypris cf. aff & & & & & & $\mathrm{C}$ \\
\hline Limnocythere sp. & & & & $\mathrm{P}$ & & \\
\hline Ilyocypris sp. & & & $\mathrm{CJ}$ & $\mathrm{P}$ & $\mathrm{C}$ & $\mathrm{V}$ \\
\hline Total taxa & 6 & 10 & 3 & 13 & 8 & 16 \\
\hline Live adult taxa & 4 & 4 & 2 & 13 & 6 & 10 \\
\hline Tolerant taxa & 2 & 3 & 1 & 4 & 3 & 7 \\
\hline Ratio (tolerant/total) & 0.3 & 0.3 & 0.3 & 0.3 & 0.4 & 0.4 \\
\hline
\end{tabular}

irregular seasonality. According to the Ostracod Watch Model, a few species were seen seasonally as in the literature (Fig. 2). The creek site revealed relatively stable ecological conditions throughout the study where there was no direct human influence observed. Unbiased diversity indices (Table 3) portrayed that the highest diversity value was found in the canal followed by the creek, wetland, and trough. More similarities and higher positive correlation were found between the wetland and the canal while the correlation was negative between the creek and wetland. Tukey's pairwise test (Table 4) supported the significant comparisons of the taxa among the sites $(p<0.01)$. This comparison was also supported by Kruskal-Wallis test which indicated a significant difference $(p<0.01$, H $($ Chi2 $)=16.7)$ between sample medians of the trough and other sites. Except for a few species with euchronal occurrences 
Table 2 Mean, maximum and minimum values of 11 environmental variables for the sites. Abbreviations: dissolved oxygen (DO, mg/ $\mathrm{L})$, percent oxygen saturation (\% DO), water $\left(\mathrm{Tw},{ }^{\circ} \mathrm{C}\right)$ and air temperature $\left(\mathrm{Ta},{ }^{\circ} \mathrm{C}\right)$, electrical conductivity (EC, $\mu \mathrm{S} / \mathrm{cm}$ ), salinity (Sal, ppt), total dissolved solids (TDS, $\mathrm{mg} / \mathrm{L})$, atmospheric pressure (Atmp, mmHg), moisture (Moist, \%), wind speed (Wsp, km/h)

\begin{tabular}{lccccccccccc}
\hline Site & $\mathrm{pH}$ & DO & \% DO & EC & Tw & Sal & TDS & Atmp & Moist & Wsp & Ta \\
\hline Creek & & & & & & & & & & & \\
Mean & 7.9 & 11.5 & 98.8 & 168.3 & 10.6 & 0.1 & 154.5 & 698.7 & 81.45 & 0.9 & 13.1 \\
Max & 8.7 & 23.8 & 188.2 & 315.9 & 19.3 & 0.2 & 303.6 & 709.1 & 98.6 & 2 & 24.2 \\
Min & 7 & 5.5 & 50.1 & 112.6 & 1.8 & 0.1 & 88.4 & 694.3 & 53.2 & 0.5 & 2.8 \\
Canal & & & & & & & & & & & \\
Mean & 7.4 & 11.5 & 101.6 & 342 & 14.07 & 0.1 & 287.8 & 699.2 & 75.25 & 1.1 & 12.9 \\
Max & 8.5 & 34.9 & 277 & 456.2 & 28.4 & 0.7 & 384.8 & 709.3 & 90.1 & 1.7 & 26 \\
Min & 3.8 & 0.3 & 3.8 & 206.4 & 4.4 & 0.1 & 191.1 & 694.4 & 54.5 & 0.4 & 2.7 \\
Wetland & & & & & & & & & & \\
Mean & 7.6 & 9.1 & 78.9 & 352.3 & 13.17 & 0.2 & 307.8 & 699.2 & 73.44 & 1 & 13.9 \\
Max & 8.4 & 28.8 & 226.4 & 412.1 & 25.1 & 0.3 & 437.5 & 709.4 & 90.1 & 1.7 & 26 \\
Min & 3.4 & 1.1 & 14.1 & 230.5 & 3.7 & 0.1 & 169.7 & 694.7 & 53.5 & 0.3 & 2.7 \\
Trough & & & & & & & & & & & \\
Mean & 8.1 & 12.4 & 108.6 & 90.9 & 12.06 & 0.1 & 81.1 & 699.1 & 74.76 & 1.0 & 13.1 \\
Max & 8.9 & 19.6 & 153.2 & 113.6 & 21.4 & 0.1 & 107.3 & 709.3 & 90.3 & 2.1 & 26.3 \\
Min & 7.1 & 7.64 & 73.4 & 59 & 0.6 & 0.03 & 47.45 & 694.6 & 52.4 & 0 & 1.2 \\
\hline
\end{tabular}

(H. incongruens, $N$. neglecta (Sars)), the rest of the species exhibited stenochronal and/or irregular occurrence patterns in each site. However, frequency of species encountered in two habitats (wetland, canal) was significantly changed after reclamation activities began in the wetland in August 2019. Consequently, these activities caused a sharp decline in quality of species richness, abundance, and changed their seasonality in the area despite the fact that total numbers (quantity) of taxa increased more than 50\% in the wetland and doubled in the canal. Such increase in the numbers of taxa was based on shifting occurrence patterns of the species and/or taxa. For example, occurrence frequency of $H$. incongruens reported from the trough was changed during the study due to irregular cleaning activities of the trough by local people. Moreover, we similarly observed that new species known the have cosmoecious characteristics arrived to the wetland after construction activities begin in the area. This is probably because of species' relatively high tolerance and/or optimum estimates for individual variables (Table 5). Accordingly, one may consider that these activities not only change the component and structure of the habitats but also provide area for those tolerant species.

Reporting a total of 15 living ostracod species is the indication of medium species diversity in the area while diversity was found relatively low per site. This was observed during the present study and was especially critical for the wetland area after the reclamation work begun (i.e., digging and diverting the site). Both richness and abundance of the species have been dramatically declined due to separation of the whole wetland area into two pieces. This activity caused serious changes in occurrence patterns and frequencies of the species as well while numbers of taxa were increased. For example, two swimming species (C. laevis and $C$. ophtalmica) were found abundant in numbers ( $>100$ specimens) from the canal and the wetland sites until August 2019. However, C. laevis (except one female found in canal) almost disappeared from both sites after dividing the area into two. In contrast, $C$. ophtalmica was only represented with a couple of individuals and a few valves and carapaces. Similar pattern was also observed for $C$. sanociensis Sywula in both sites. Below we provide species specific characteristics for the most common species unless otherwise indicated.

Cypria ophtalmica is one of the most common species reported from different types of aquatic bodies such as ponds, the littoral zone of lakes, streams, springs, and cave waters (Meisch 2000b; Rossetti et al. 2006; Alkalaj et al. 2019). This is probably due to its high levels of tolerance ranges to environmental variables (Külköylüoğlu 2000). Alkalaj et al. (2019) argued that $C$. ophtalmica was one of the most common species in Iceland lakes and cave pools (except springs) where it was reported from very cold 

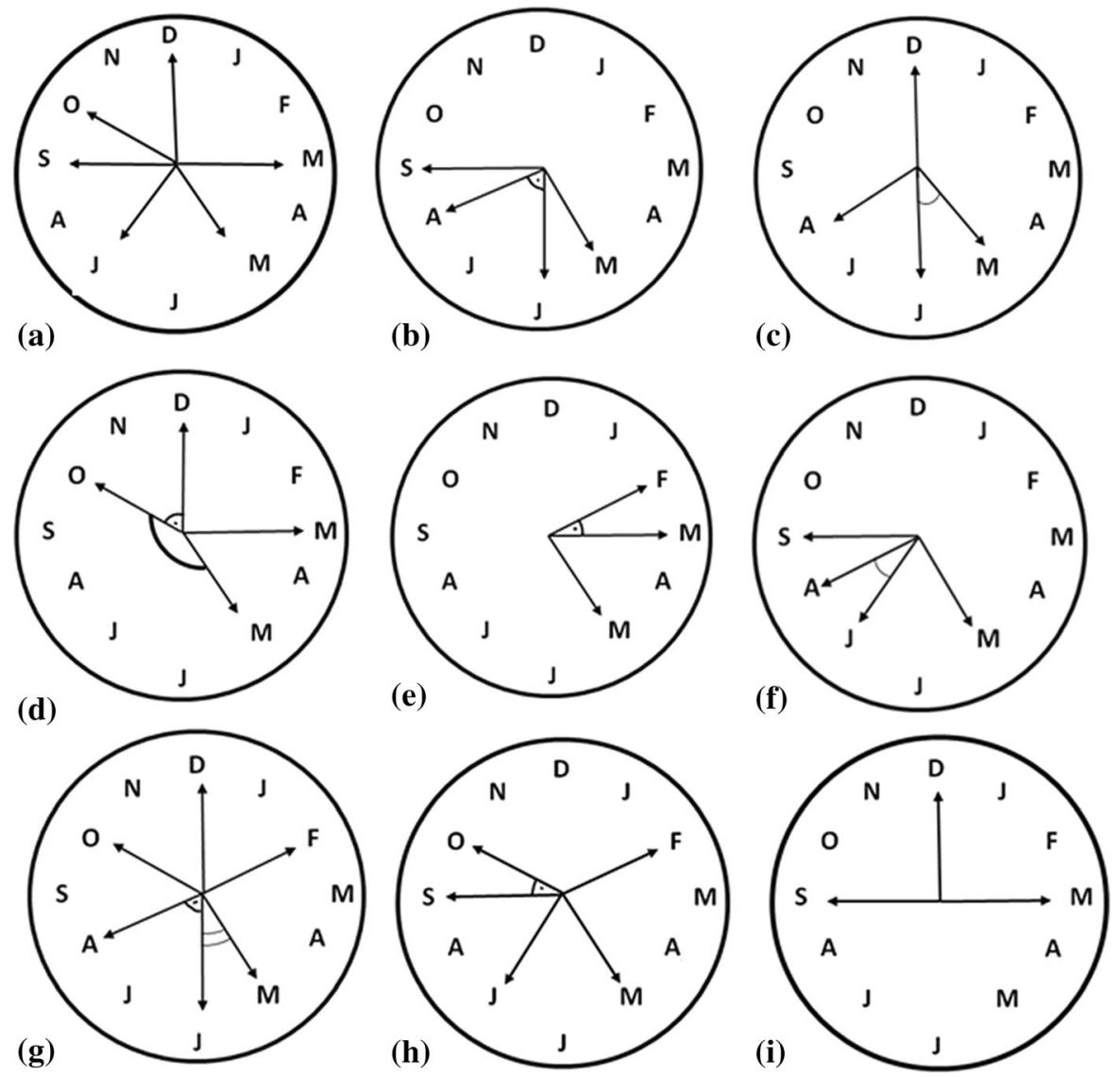

Fig. 2 a Neglecandona neglecta in the canal (not reported in April, June and August) and in the creek (not in January and February); b Candona sanociensis species in the wetland (angle), in the canal and creek (see text for explanation); c Cyclocypris laevis in the canal (angle) and in the wetland ( $\mathbf{J}$ and A, not July); d Heterocypris incongruens in the trough (wide angle) and in the canal (narrow angle); e Ilyocypris inermis in

Table 3 Unbiased diversity results with 9999 bootstrap

\begin{tabular}{lllll}
\hline & Creek & Trough & Canal & Wetland \\
\hline Taxa_S & 13 & 3 & 16 & 11 \\
Shannon_H & 2.1 & 0.7 & 2.3 & 1.9 \\
Evenness_e^H/S & 0.6 & 0.7 & 0.6 & 0.6 \\
Brillouin & 1.7 & 0.5 & 1.9 & 1.6 \\
Menhinick & 3.6 & 1.7 & 4.1 & 3.3 \\
Margalef & 4.6 & 1.8 & 5.6 & 4.2 \\
\hline
\end{tabular}

$\left(6.6{ }^{\circ} \mathrm{C}\right)$ and even high conductivity value (e.g., $4950 \mu \mathrm{S} / \mathrm{cm})$. However, the authors failed to report some of those earlier studies (e.g., see Delorme 1991; the creek (angle pointed and in May) and in the canal (in March); f Eucypris virens species in the wetland (angle) and in the canal; g Cypria ophtalmica species in the wetland (angle pointed) and in the canal (double angle); $\mathbf{h}$ Herpetocypris brevicaudata in the creek. Note to single occurrence in May from the trough; j Psychrodromus olivaceus in the creek seen in three months

Table 4 Results of Tukey's pairwise test comparisons show significant difference between the trough and two other sites (canal and wetland) $(p<0.01)$

\begin{tabular}{lllll}
\hline & Creek & Canal & Wetland & Trough \\
\hline Creek & & 0.6 & 0.9 & 0.02 \\
Canal & 1.7 & & 0.3 & 0.002 \\
Wetland & 0.8 & 2.6 & & 0.1 \\
Trough & 4.3 & 6.0 & 3.5 & \\
\hline
\end{tabular}

Bellavere et al. 1999; Külköylüoğlu 2000, 2004) where maximum and minimum ranges of some of the ecological variables were already higher than what 
Table 5 Tolerance (Tol) and optimum (Opt) estimates of 11 species occurring three or more times during the study. N2, Hill's coefficient (numbers of occurrences). See Table 2 for abbreviations

\begin{tabular}{|c|c|c|c|c|c|c|c|c|c|}
\hline \multirow[t]{2}{*}{ Species } & \multirow[t]{2}{*}{$\mathrm{N} 2$} & \multicolumn{2}{|l|}{$\mathrm{pH}$} & \multicolumn{2}{|l|}{ DO } & \multicolumn{2}{|l|}{$\mathrm{EC}$} & \multicolumn{2}{|l|}{ Tw } \\
\hline & & Opt & Tol & Opt & Tol & Opt & Tol & Opt & Tol \\
\hline Neglecandona neglecta & 14 & 7.2 & 1.8 & 12.1 & 10.8 & 297.1 & 82.4 & 14.2 & 8.8 \\
\hline Fabaeformiscandona fabaeformis & 3 & 7.8 & 0.6 & 6.9 & 7.4 & 367.9 & 29.4 & 15.5 & 8.1 \\
\hline Candona sanociensis & 13 & 7.9 & 0.4 & 6.5 & 7.4 & 261.6 & 86.4 & 17.7 & 6.2 \\
\hline Cyclocypris laevis & 7 & 7.9 & 0.4 & 6.1 & 5.3 & 364.7 & 71.2 & 15.7 & 7.8 \\
\hline Cypria ophtalmica & 14 & 7.4 & 1.4 & 11.1 & 10.5 & 337.5 & 67.3 & 13.3 & 7.9 \\
\hline Herpetocypris brevicaudata & 7 & 8.1 & 0.3 & 10.7 & 6.1 & 190.8 & 82.6 & 9.7 & 4.0 \\
\hline Psychrodromus olivaceus & 6 & 7.7 & 0.6 & 12.5 & 5.9 & 171.1 & 27.7 & 8.5 & 4.8 \\
\hline Eucypris virens & 5 & 8.1 & 0.3 & 2.4 & 2.2 & 288.8 & 42.7 & 21.9 & 5.7 \\
\hline Heterocypris incongruens & 13 & 7.9 & 1.1 & 11.1 & 4.1 & 171.0 & 123.0 & 14.2 & 5.6 \\
\hline Ilyocypris gibba & 3 & 8.2 & 0.1 & 10.1 & 3.5 & 212.1 & 133.0 & 15.3 & 0.9 \\
\hline Ilyocypris inermis & 5 & 8.0 & 0.7 & 13.1 & 8.4 & 244.5 & 147.0 & 9.9 & 5.5 \\
\hline
\end{tabular}

they reported. Additionally, C. ophtalmica was reported from a heavily polluted lake (Lake Yeniçağa) in Turkey where it was collected in two separate seasons (April-May, July-October) (no species were recovered in September) (Külköylüoğlu et al. 2007). Meisch (2000) stated that the species can be seen throughout the year with about two generations. Külköylüoğlu et al. (2014), who provided detailed information about its ecology, reported the species from late June to December in a natural lake (Lake Çubuk) in Turkey while it was commonly found in a variety of aquatic habitats in northern Italy between May and December (Rossetti et al. 2006). In Portugal, C. ophtalmica was collected from ponds in three months (December, January, April) (Martins et al. 2010). We found $C$. ophtalmica in the wetland and canal within the known ecological ranges (Table 2). Although it was located on the positive site of the CCA diagram (Fig. 3) closer to EC, there was no direct correlation between EC and the species. This implies a possibility of the species high tolerances to EC values. While the species was observed during two time periods (May-June, November-December) in the canal, its occurrence was irregular in the wetland (Fig. 2). Accordingly, putting all this information together, these results support the earlier view of Meisch (2000) that the species has probably two generations per year.

Cyclocypris laevis is another tolerant species almost co-occurred with $C$. ophtalmica from the canal and wetland sites. Similar to $C$. ophtalmica, the species has been encountered from variety of habitats

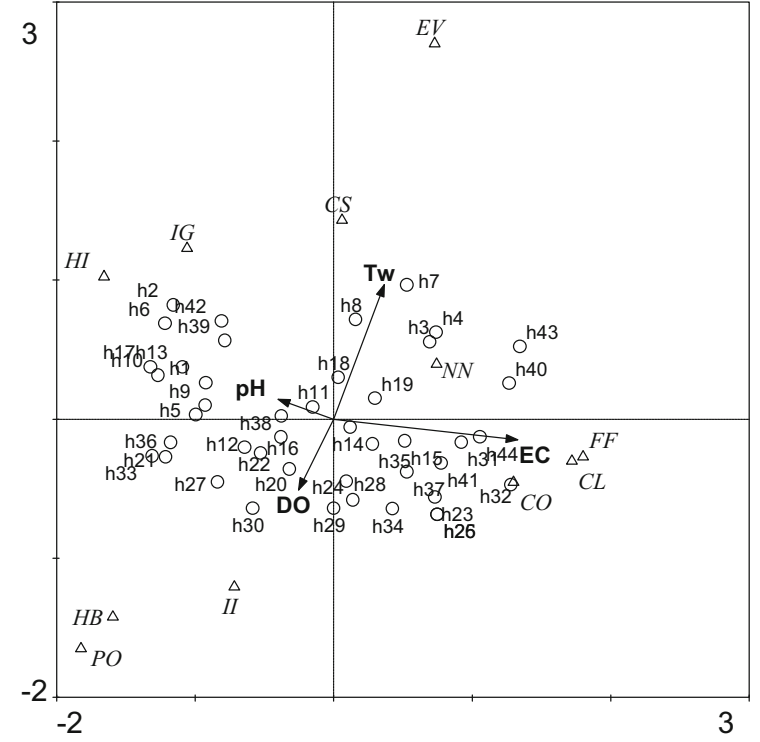

Fig. 3 CCA diagram shows correlations between 11 ostracod taxa (angle) reported three or more times during the present study and four environmental variables (arrows) among 44 samplings (circles). Species abbreviations: NN, Neglecandona neglecta; FF, Fabaeformiscandona fabaeformis; CS, Candona sanociensis; CL, Cyclocypris laevis; CO, Cypria ophtalmica; HB, Herpetocypris brevicaudata; PO, Psychrodromus olivaceus; EV, Eucypris virens; HI, Heterocypris incongruens; IG, Ilyocypris gibba; II, Ilyocypris inermis

such as pools, ponds, springs, streams, and lakes in Europe all year around (Meisch 2000), but it is not common in Turkey. In Belarus, this species was found from stagnant littoral zones of Minsk Lake, and creeks and springs flowing to it (Keyser and Nagorskaya 1998). Although the authors stated that their study was 
conducted in monthly basis from 1994 to 1996, they did not specify monthly occurrences of the species. However, similar to Meisch (2000), they underlined that $C$. laevis had one annual generation and adults could tolerate the winter conditions. Although the species was reported within the known ecological ranges, its occurrence from the sites was very limited within two or three months from May to June in the canal, but this pattern was patchy in the wetland (Fig. 2). We consider this difference was highly related to habitat destruction of the wetland because C. laevis illustrated a sharp disappearance from the site after the construction begun at the wetland site. This, indeed, can be supported when the species was correlated with EC in CCA diagram (Fig. 3).

Candona sanociensis had similar occurrence with C. laevis from the wetland between June and August, corresponding to the occurrence in the creek (except September) but was also collected from the canal in May and September (no live individuals observed between). However, this range covers the one seen for the former two sites. This species has broad habitat preferences reported from streams, springs, roadside pool, river, creeks, pool, wells, and groundwater (Sywula 1971; Danielopol 1978; Meisch 2000; Külköylüoğlu et al. 2020b). Gürer and Külköylüoğlu (2019) reported this species from a shallow lake in Turkey where it was collected in two different periods of a year (February-June, September-October). These authors underlined that there was continuous flowing spring water into their sampling site where the species was collected with a slightly acidic to alkaline $(\mathrm{pH}$ 6.3-8.9) and cool to warm water $\left(7.5-26.6^{\circ} \mathrm{C}\right)$. CCA diagram portrays relatively weak correlation between C. sanociensis and water temperature, suggesting species may have higher tolerance ranges to changes in temperature. However, there is not much information available about the ecological and seasonal occurrence of the species making it difficult to outline general conclusions.

On the other hands, as mentioned above, such human activity might have been providing advantages for some tolerant species with wide geographical distribution (Külköylüoğlu 2013; Yavuzatmaca et al. 2018). Indeed, five species (H. incongruens, H. salina (Brady), I. bradyi Sars, I. gibba Ramdohr, I. inermis Kaufmann) were able to reach to the canal after the construction activity where they were absent before. As it was suggested (Külköylüoğlu 2013; Akdemir et al. 2016; Ghaouaci et al. 2017; Yavuzatmaca 2020), these kind of species with cosmopolitan characteristics can be called a cosmoecious species due to their wide geographical distribution in variety of habitats and relatively high ecological tolerance ranges to different environmental variables. Therefore, they can survive even in highly disturbed or polluted habitats. This is probably what happened in our two sampling sites (i.e., canal and wetland). Changing the water structure and conditions in these sites resulted in the species facing chaos in their natural habitat. Thereby, most (if not all) of the non-tolerant species or species without a fast response to these changes vanished. This could provide more space for those invader (i.e., cosmoecious or cosmopolitan) species in their ecological succession (Külköylüoğlu 2009). For example, $H$. incongruens, one of the most common species, is found at all the disturbed sites. Fryer (1997) called it as "horse-trough ostracod" due to its abundance in troughs. However, in reality, the species can be very common and its abundance can be very high in many different types of shallow aquatic bodies including pools, ponds, creeks, troughs, and ditches (Meisch 2000). In our case, H. incongruens was the only dominant live species in the trough, but it was also reported from the wetland and canal within its expected occurrence pattern (Fig. 2). Besides, locating the species in the opposite site of the influential two variables (EC, Tw) on the CCA diagram (Fig. 3) supports that it did not show significant correlation to any of those variables used in here.

Unlike $H$. incongruens, I. bradyi and I. gibba were seen one and two times in October and September 2019 in the canal, respectively. Another species of this genus, I. inermis was sampled from the creek between February and May (April 2020 samples were not collected). This species was once considered to be rare, but recent studies (Sar1 et al. 2012; Yavuzatmaca et al. 2018; Batmaz et al. 2020) showed that this is due to its similarities to I. bradyi. This can at least be true since both species bear short or reduced swimming setae in the second antenna. Besides this, the carapaces of these species have close similarities too. Thus, considering these similarities, we believe that the species might have been confused with I. bradyi and probably has a broader distributional range and occurrences than what is known.

Contrasting to the species I. bradyi, I. gibba is not a common species in Turkey and there is not much 
information about its ecology and seasonality. This restricts us to make general conclusions about I. gibba. Moreover, it is surprising since the species is also known with its cosmopolitan features and has been reported from variety of habitats (see details in Meisch 2000; Külköylüoğlu 2000). In addition to this, we found two females of $H$. salina once from the canal. One may expect to observe this species more commonly from such habitats due to its high levels of tolerances (e.g., see Ghaouaci et al. 2017; Yavuzatmaca 2020).

Conversely, species assemblage was found different in the creek than the other three sites. Three species (P. olivaceus, H. brevicaudata, P. zenkeri) found from the creek were reported within their expected seasonal occurrences from fall to winter months, of which there was only one female of $P$. zenkeri found in July 2019; therefore, we did not have enough information about this species to discuss here. Nevertheless, our findings of other species (Fig. 2) seem to correspond to the literature, but exceptions are also seen (Meisch 2000). For example, in a natural spring, Külköylüoğlu et al. (2014) continued their monthly sampling for more than a year and found that adults and juveniles of $P$. olivaceus with an annual occurrence during their study. This species appears to prefer creeks, springs, and ponds fed by springs implying that $P$. olivaceus can be considered a habitat-specific species mostly found in natural water bodies or artificial waters (e.g., trough) not disturbed by human activities (Külköylüoğlu and Yılmaz 2017).

Herpetocypris brevicaudata has been known to have relatively rare occurrences from ditches, creeks, springs, and littoral zones of lakes (Roca \& Baltanás 1993; Roca and Wansard 1997; Meisch 2000; Külköylüoğlu and Sar1 2012). Beyer et al. (1997) reported the species from the water bodies in Canary Islands between April and December. Smith (2005) sampled the species accompanied with $H$. incongruens from a cattle trough in Sittingbourne (United Kingdom) in December and January where the water temperature was $3^{\circ} \mathrm{C}$ and $\mathrm{pH}$ 7.6. We observed the species from the creek with a very patchy seasonal occurrence within the expected seasons. Smith (2005) pointed out the possibility of two forms of the species which can be encountered in warm and cold waters. Külköylüoğlu et al. (2017a, c) underlined that the species can be seen in cool-cold springs (or spring related waters) in Turkey as long as ecological conditions of the waters were stagnant. Since we do not have detailed information about $H$. brevicaudata, a general conclusion is not easy to make. Hence, further studies are suggested.

Neglecandona neglecta is another bottom-dependent species due to lack of swimming setae that it was found in the creek on two separate months (December and March), but no individuals were found between. There were only a couple of juveniles collected from the canal while bisexual adults were collected from March to October in the wetland. The species was located between the arrows of EC and Tw (Fig. 3), suggesting that fluctuations on these variables can be effective. This is one of the most common species worldwide known to have high levels of tolerances to ecological variables (Meisch 2000; Karanovic 2012; Yavuzatmaca et al. 2018; Batmaz et al. 2020). However, it seems that the species mostly prefers cool well oxygenated waters.

Similar to N. neglecta, a total of five individuals (1 male 4 females) of $F$. fabaeformis (Fischer) were found from the canal within its expected occurrence in May (Hiller 1972; Meisch 2000). This species was reported almost all year around from a karstic spring (Bolu, Turkey) where minimum and maximum water temperatures were 13.9 and $25.1{ }^{\circ} \mathrm{C}$, electrical conductivity was 881-2046 $\mu \mathrm{S} / \mathrm{cm}, \mathrm{pH}$ 6.3-7.7 (see details in Çelekli and Külköylüoğlu 2007). Comparing to other species, the authors claimed that $F$. fabaeformis had higher tolerances to EC values than indicated in the literature. Indeed, Fig. 2 illustrates supportive evidence for this view when finding the species closer to EC arrow on the CCA diagram. Ecological information of the species needs to be evaluated in future studies.

Among the species, another tolerant one is E. virens. The species was indeed located away from the arrow of the water temperature on CCA diagram, underlining that temperature was not effective on its occurrences during the present study. This species has a common geographic distribution (Meisch 2000; Roca et al. 2000; Ghaouaci et al. 2017) but mostly prefers stagnant water bodies. The species has a stenochronal occurrence (Meisch 2000) which underlines that adults can be found in April and May when the larvae appear in late February and early March. Populations with males and females (and juveniles) of E. virens were even reported most frequently from saline water bodies (0.07 to $14.51 \%$ ) in Sahara 
(Northern Algeria) (Ghaouaci et al. 2017). The species was recorded from a heavily polluted Lake Yeniçağa in May-June and November (Külköylüoğlu et al. 2007). Eucypris virens was reported from May to September in the canal (see exception in Fig. 2). Although patchy, our findings are in the range of its seasonal distribution. The species is also known to tolerate relatively high salinity ranges (Meisch 2000; Yavuzatmaca 2020). According to Koenders et al. (2012), the species has mixed reproduction with Holarctic distribution in Europe where it shows 35 or more cryptic forms. Such differences might influence the species distribution among the sites and might explain species patchy occurrences. Külköylüoğlu et al. (2019) argued that species with lower optimum values portrayed tendency to have higher tolerances for different environmental variables. It has been known that $E$. virens exhibits wide range of temperature tolerance (Bronstein 1947, Smith and Martens 1996; Akdemir and Külköylüoğlu 2011, 2014) that it is not entirely surprising to find this at the range of $14-28{ }^{\circ} \mathrm{C}$ in the present work.

Our results support this view that species (e.g., $N$. neglecta, C. ophtalmica, P. olivaceus) known with cosmopolitan characteristics exhibited higher optimum values when tolerance was lower than noncosmopolitans (see Table 5). However, as the authors stated, such relationship can be associated with several factors such as types of environmental variables, sampling size, and/or biological factors. As mentioned before, we were not able to include biological factors and also our data were limited with abiotic factors. We reported that EC $(\mathrm{F}=3.95 ; p=0.002)$ and Tw $(\mathrm{F}=1.92 ; p=0.03)$ were the two influential variables correlated with several ostracods during the study. The correlation was about $78.6 \%$, but variance (13.1) was slightly high. Although valuable, finding this correlation high can be related to lack of variables we used. Therefore, we cannot make general conclusion about this correlation but pinpoint the needs of future studies.

\section{Conclusion}

Both natural and artificial habitats are under the stress of human activities. Thus, this implies unexpected occurrence patterns in species. Indeed, our results indicated that anthropogenic activities caused negative impact on species diversity and richness that were critically dropped down and did not recover during the study. Besides, our findings support the results of earlier studies (e.g., Hokkanen and Pimentel 1984; Kirkpatrick and Barton 1997; Külköylüoğlu 2004; Külköylüoğlu et al. 2017c) that increasing numbers of cosmopolitan and/or invader species in natural habitats (i.e., Hıdırşeyhler wetland) can cause a decline in the fauna and/or flora of that ecosystem (i.e., ostracod assemblages). Turkey has about 135 wetlands of variable size, shape, and types in about 2 206835 ha of surface area, only 13 of which have been accepted as "Ramsar sites" by the Ramsar Convention. However, most of these (and unprotected) habitats are still under the threat of human activities. In global perspective, this might be referred to as mongrelization "dominancy of cosmopolitan species" (Meffe and Carroll 1994). In this case, anthropogenic activities on the study area were the main reason of changing the species assemblages and structures (Külköylüoğlu 1999; Roca et al. 2000; Çelekli and Külköylüoğlu 2007). We strongly recommend that such natural habitats without considering the size and/or shape should be protected and conserved before it is too late.

Acknowledgements We thank Dr. Randy Gibson (San Marcos Aquatic Resources Center, USFWS, Texas, USA) for his review and suggestions on earlier version of the study. Also, Filiz Batmaz (Bolu Abant İzzet Baysal University, Turkey) is thanked for her help during laboratory works.

Authors' contributions All authors joined field and laboratory works equally. OK provided conceptual approach, made species description, analyzed the data, and wrote the main parts of the manuscript. $\mathrm{BC}$ and $\mathrm{AA}$ filtered and separated the samples, worked on identification, contributed in writing the manuscript along with preparing tables and figures. All authors read and approved the final manuscript.

Funding Not applicable.

Data availability All species kept in the Limnology Laboratory of Bolu Abant İzzet Baysal University are available upon request from the corresponding author.

\section{Declarations}

Conflict of interest The authors declare that they have no conflict of interest to declare 


\section{References}

Akdemir D, Külköylüoğlu O (2011) Freshwater Ostracoda (Crustacea) of Diyarbakır Province with a new report for Turkey. Turk J Zool 35:671-675

Akdemir D, Külköylüoğlu O (2014) Preliminary study on distribution, diversity, and ecological characteristics of nonmarine Ostracoda (Crustacea) from the Erzincan region (Turkey). Turk J Zool 38:421-431

Akdemir D, Külköylüoğlu O, Yavuzatmaca M, Sarı N (2016) Freshwater ostracods (Crustacea) of Gaziantep (Turkey) and their habitat preferences according to movement ability. Fundam Appl Limnol 187(4):307-314. https://doi. org/10.1127/fal/2016/0665

Alkalaj J, Hrafnsdottir T, Ingimarsson F, Smith RJ, Kreiling A-K, Mischke S (2019) Distribution of Recent non-marine ostracods in Icelandic lakes, springs, and cave pools. J Crust Biol. https://doi.org/10.1093/jcbiol/ruz008

Ataol M, Onmuş O (2021) Wetland loss in Turkey over a hundred years: implications for conservation and management. Ecosyst Health Sustain 7(1):1930587. https://doi. org/10.1080/20964129.2021.1930587

Batmaz F, Külköylüoğlu O, Akdemir D, Yavuzatmaca M (2020) Effective roles of ecological factors on nonmarine Ostracoda (Crustacea) in shallow waters of Malatya (Turkey). Ecol Res 35:511-523

Bellavere C, Benassi G, McKenzie KG, Rossi V (1999) Non marine Ostracoda (Crustacea) from temporary ponds in the Isole Pelagie (Sicily Italy). Geosound 35:29-38

Beyer GC, Meisch C, Wouters K (1997) New records of freshwater Ostracoda (Crustacea) from La Gomera, El Hierro, Fuerteventura and Tenerife (Canary Islands). Bull Soc Nat Luxemb 98:239-259

Bronhstein ZS (1947) Fresh-water Ostracoda. Fauna of the USSR, Crustaceans, V.2. No.1. Russian Translation Series, 64, Academy of Sciences of the USSR Publishers, Moscow, Russia (English translation 1988); Amerind Publishing Company, New Delhi.

Çelekli A, Külköylüoğlu O (2007) On the relationship between ecology and phytoplankton composition in a karstic spring (Çepni, Bolu). Ecol Indic 7(2):497-503. https://doi.org/10. 1016/j.ecolind.2006.02.006

Danielopol D (1978) Ueber Herkunft und Morphologie der süsswasserhypogäischen Candoninae Crustacea, Ostracoda. Sitz Be Oesterr Akad Wiss Math Nat KI Abt I 187:1-162

Delorme LD (1991) Ostracoda. In: Thorpe JH, Covich AP (eds) Ecology and classification of North American invertebrates. Academic Press Inc, Boston

Fryer G (1997) The horse-trough ostracod heterocypris incongruens. Naturalist 122:121-135

Ghaouaci S, Yavuzatmaca M, Külköylüoğlu O, Amarouayache M (2017) An annotated checklist of the non-marine ostracods Crustacea of Algeria with some ecological notes. Zootaxa 4290(1):140-154. https://doi.org/10.11646/ zootaxa.4290.1.8

Gürer U, Külköylüoğlu O (2019) Limnoecological characteristics and seasonal distribution of Ostracoda (Crustacea) in a natural lake (Lake Karagöl) and a man-made reservoir
(Lake Uşak) in northeastern Turkey. Bull Soc Nat Luxemb 121:277-289

Herath G (2004) Incorporating community objectives in improved wetland management: the use of the analytic hierarcy process. J Environ Manage 70:263-273

Hiller D (1972) Untersuchungen zur Biologie und zur Ökologie limnischer Ostracoden aus der Umgebung von Hamburg. Arch Hydrobiol Suppl Bd 40(4):400-497

Hoff CC (1943) Seasonal changes in the Ostracod fauna of temporary ponds. Ecology 24(1):116-118

Hokkanen H, Pimentel D (1984) New approach for selecting biological control agents. Can Entomol 116:1109-1121. https://doi.org/10.4039/Ent1161109-8

Horne FR (1993) Survival strategy to escape desiccation in a freshwater ostracod. Crustaceana 65(1):53-61

Hurlbert ST (1984) Pseudoreplication and the design of ecological field experiments. Ecol Monogr 54(2):187-211

Juggins S (2003) Software for ecological and palaeoecological data analysis and visualization C2 User Guide. University of Newcastle, Newcastle-upon- Tyne, UK

Karanovic I (2012) Recent freshwater ostracods of the world: Crustacea, Ostracoda. Podocopida, Springer Science and Business Media, Heidelberg

Kempf EK (1980) Index and Bibliography of Nonmarine Ostracoda. Parts 1-4. Sonderveröff. geol. Inst. Köln 35 (Index A): 1-188; 36 (Index B): 1-180; 37 (Index C): 1-204; 38 (Bibliography A): 1-186.

Kempf EK. 1997. Index and Bibliography of Nonmarine Ostracoda. Parts 6 and 7. Sonderveröff. geol. Inst. Köln 109 (Part 6: Index A Supplement 1): 1-142; 110 (Part 7: Index B Supplement 1): 1-134; 111 (Part 8: Index C Supplement 1): 1-152; 112 (Part 9: Bibliography C): 1-144.

Keyser D, Nagorskaya L (1998) Ostracods in the vicinity of Minsk, Belarus. Mitt Hamb Zool Mus Inst 95:115-131

Kirkpatrick M, Barton NH (1997) Evolution of a Species' Range. Am Nat 150(1):1-23. https://doi.org/10.1086/ 286054

Koenders A, Martens K, Halse S, Schön I (2012) Cryptic species of the Eucypris virens species complex (Ostracoda, Crustacea) from Europe have invaded Western Australia. Biol Invasions 14:2187-2201

Külköylüoğlu O (1998) Freshwater Ostracoda (Crustacea) and their quarterly occurrence in Şamlar Lake (İstanbul, Turkey). Limnologica 28(2):229-235

Külköylüoğlu O (1999) Seosanal distribution of freshwater Ostracoda (Crustacea) in springs of Nevada. Yerbilimleri (geosound) 35:85-91

Külköylüoğlu O (2004) On the usage of ostracods (Crustacea) as bioindicator species in different aquatic habitats in the Bolu region, Turkey. Ecol Indic 4:139-147. https://doi.org/10. 1016/j.ecolind.2004.01.004

Külköylüoğlu O (2009) Ecological succession of freshwater Ostracoda (Crustacea) in newly developed Rheocrene Spring (Bolu, Turkey). Turk J Zool 33:115-123. https:// doi.org/10.3906/zoo0712-12

Külköylüoğlu O (2013) Diversity, distribution and ecology of nonmarine Ostracoda (Crustacea) in Turkey: Aplications of pseudorichness and cosmoecious species concepts. Recent Research Developments in Ecology 4:1-18 
Külköylüoğlu O, Sarı N (2012) Ecological characteristics of the freshwater Ostracoda in Bolu Region (Turkey). Hydrobiologia 688:37-46

Külköylüoğlu O, Yılmaz O (2017) Seasonal changes of ostracods in troughs (Bolu, Turkey). Rev Hydrobiol 10(2):99-105

Külköylüoğlu O, Dügel M, Kılıc M (2007) Ecological requirements of Ostracoda (Crustacea) in a heavily polluted shallow lake, Lake Yeniçağa (Bolu, Turkey). Hydrobiologia 585:119-133

Külköylüoğlu O, Akdemir D, Yüce R (2012) Distribution, ecological tolerance and optimum levels of freshwater Ostracoda (Crustacea) from Diyarbakır, Turkey. Limnology 13:73-80. https://doi.org/10.1007/s10201-011-0357-1

Külköylüoğlu O, Sarı N, Dügel M, Dere Ş, Dalkıran N, Aygen C, Çapar Dinçer S (2014) Effects of limnoecological changes on the Ostracoda (Crustacea) community in shallow lake (Lake Çubuk, Turkey). Limnologica 46:99-108. https://doi.org/10.1016/j.limno.2014.01.001

Külköylüoğlu O, Yavuzatmaca M, Tanyeri M, Yilmaz O (2017a) Ostracoda (Crustacea) species composition and environmental correlates in different aquatic habitats of the Zonguldak and Bartın regions (Turkey). Turk J Zool 41:686-695. https://doi.org/10.3906/zoo-1512-36

Külköylüoğlu O, Yılmaz S, Yavuzatmaca M (2017b) Comparison of Ostracoda (Crustacea) species distribution, diversity and ecological characteristics among habitat types. Fundam Appl Limnol 190(1):63-86

Külköylüoğlu O, Tanyeri M, Y1lmaz O (2017c) Alpha and beta species diversity of freshwater Ostracoda (Crustacea) and their seasonal distribution in Seben-Taşliyayla Reservoir (Bolu, Turkey). Turk J Fish Aquat Sci 17:1357-1365. https://doi.org/10.4194/1303-2712-v17-6-28

Külköylüoğlu O, Akdemir D, Yavuzatmaca M, Çelen E, Dere Ş, Dalkıran N (2019) Do reproductive modes and swimming abilities influence occurrence of non-marine ostracod (Crustacea) species among aquatic habitats? Zoolog Sci 36(6):511-520. https://doi.org/10.2108/zs180193

Külköylüoğlu O, Yavuzatmaca M, Yılmaz O (2020a) A new species of the genus Pseudostrandesia (Ostracoda: Crustacea) and first report of the genus from Palaearctic region. Zool Middle East 66(1):37-45. https://doi.org/10.1080/ 09397140.2020 .1675993

Külköylüoğlu O, Yavuzatmaca M, Yılmaz O (2020b) Ecology and distribution of ostracods in Mardin and Muş provinces in Turkey. Biologia 75:1855-1870. https://doi.org/10. 2478/s11756-020-00439

Külköylüoğlu O, Hutchins BT, Yavuzatmaca M, Schwartz BF (2021) Hyporheic ostracods (Crustacea, Ostracoda) from Texas (USA) with six new species. Zootaxa 5046(1):001-063

Külköylüoğlu O (2000) The importance of cosmopolitan and indicator species of Ostracoda (Crustacea) in Turkey based on some water parameters. Sinop Water Product Conference 2000:421-437. (Abstract in Turkish)

Martins MJF, Namiotko T, Cabral MC, Fatela F, Boavida MJ (2010) Contribution to the knowledge of the freshwater Ostracoda fauna in continental Portugal, with an updated checklist of Recent and Quaternary species. J Limnol 69:160-173
Meffe GK, Carroll CR (1994) Principles of conservation biology. Sinauer Associates, Inc. Massachusetts, U.S.A. (pp. 600). doi: https://doi.org/10.2307/1382767

Meisch C, Smith RJ, Martens K (2019) A subjective global checklist of the extant non-marine Ostracoda (Crustacea). Eur J Taxon 492:1-135

Meisch C (2000) Freshwater Ostracoda of Western and Central Europe. Süsswasserfauna von Mitteleuropa 8/3. Spektrum Akademischer Verlag, Heidelberg

Mitsch WJ, Gosselink JG (2015) Wetlands. Wiley, New Jersey

Ozawa H (2013) The history of sexual dimorphism in Ostracoda (Arthropoda, Crustacea) since the Palaeozoic. In: Moriyama $\mathrm{H}$ (ed) sexual dimorphism. Intech Publication

Proctor VW (1964) Viability of crustacean eggs recovered from ducks. Ecology 45:656-658

Roca JR, Baltanás A (1993) Ecology and distribution of Ostracoda in Pyrenean springs. J Crust Biol 13:165-174

Roca JR, Wansard G (1997) Temperature influence on development and calcification of Herpetocypris brevicaudata Kaufmann, 1900 (Crustacea: Ostracoda) under experimental conditions. Hydrobiologia 347:91-95. https://doi. org/10.1023/A:1003067218024

Roca JR, Mezquita F, Rueda J, Camacho A, Miracle MR (2000) Endorheic versus karstic lake: patterns of ostracod distributions and lake typology in a Mediterranean landscape (Castilla - La Mancha, Spain). Mar Freshw Res 51:311-319

Rossetti G, Bartoli M, Martens K (2004) Limnological characteristics and recent ostracods (Crustacea, Ostracoda) of freshwater wetlands in the Parco Oglio Sud (Northern Italy). Ann Limnol Int J Lim 40:329-341

Rossetti G, Martens M, Meisch C, Tavernelli S, Pieri V (2006) Small is beautiful: diversity of freshwater ostracods (Crustacea, Ostracoda) in marginal habitats of the province of Parma (Northern Italy). J Limnol 65:121-131

Sarı N, Külköylüoğlu O, Akdemir D (2012) First record and detailed description of the male of Ilyocypris inermis Kaufmann, 1900 (Crustacea, Ostracoda). Turk J Zool 36(4):484-495. https://doi.org/10.3906/zoo-1012-78

Scharf B, Herzog M, Pint A (2016) New occurrences of Cyprideis torosa (Crustacea, Ostracoda) in Germany. J Micropalaeontol 36:120-126

Smith RJ (2005) A new UK record of Herpetocypris brevicaudata Kaufmann, 1900 (Cypridoidea, Ostracoda): palaeotemperature implications. J Micropalaeontol 24:177-178. https://doi.org/10.1144/jm.24.2.177

Smith RJ, Martens K (1996) On Eucypris virens (Jurine). Stereo-Atlas Ostracod Shells 23(14):61-88

Sywula T (1971) Notes on Ostracoda 11: New taxa of the nominate subgenus of genus Candona Baird from Poland. Bull Acad Polon Sci Ser Sci Biol 19:587-591

ter Braak CJF (1986) Canonical correspondence analysis: a new eigenvector technique for multivariate direct gradient analysis. Ecology 67:1176-1179

Uçak S, Külköylüoğlu O, Akdemir D, Başak E (2014) Distribution, diversity and ecological characteristics of freshwater Ostracoda (Crustacea) in shallow aquatic bodies of the Ankara region, Turkey. Wetlands 34:309-324. https:// doi.org/10.1007/s13157-013-0499-5 
Vinyard G (1979) An ostracod (Cypriodopsis vidua) can reduce predation from fish by resisting digestion. Am Midl Nat 102:188-190. https://doi.org/10.2307/2425084

Williams M, Siveter DJ, Ashworth AC, Wilby PR, Horne DJ, Lewis AR, Marchant DR (2008) Exceptionally preserved lacustrine ostracods from the Middle Miocene of Antarctica: implications for high-latitude palaeoenvironment at $778^{\circ}$ South. Proc R Soc B. https://doi.org/10.1098/rspb. 2008.0396

Wise CD (1961) Taxonomy and Ecology of fresh-water ostracods of south-central Texas. Dissertation, The University of New Mexico

Yavuzatmaca M (2019) Comparative analyses of non-marine Ostracods (Crustacea) among water basins in Turkey. Acta Zool Acad Sci Hung 65(3):269-297. https://doi.org/10. 17109/AZH.65.3.269.2019

Yavuzatmaca M (2020) Species assemblages of Ostracoda (Crustacea) from west-site of Turkey: their indicator potential for lotic and lentic habitats. Biologia 75:2301-2314. https://doi.org/10.2478/s11756-02000494-y

Yavuzatmaca M, Külköylüoğlu O, Akdemir D, Çelen E (2018) On the relationship between the occurrence of ostracod species and elevation in Sakarya Province, Turkey. Acta Zool Acad Sci Hung 64:329-354. https://doi.org/10.17109/ AZH.64.4.329.2018

Zhang C, Robinson D, Wang J, Liu J, Liu X, Tong L (2011) Factors influencing farmers' willingness to participate in the conversion of cultivated land to wetland program in Sanjiang National Nature Reserve, China. Environ Manage 47:107-120

Publisher's Note Springer Nature remains neutral with regard to jurisdictional claims in published maps and institutional affiliations. 